\title{
Micro Enterprise and Women Empowerment through Self Help Groups: A Study of Allahabad District in Uttar Pradesh
}

\author{
* Ms. Pratibha \\ ** Prof. Sadhna Singh
}

\section{Abstract}

Women comprise fifty percent of the world population and receive only just ten percent of the world income and possessor of even less than one percent of world's property. Women suffer many disadvantages as compared to men in terms of literacy, labor participation and earnings. The major strategies for women empowerment include social empowerment, political empowerment and gender equality along with demo- graphical justice (rural and urban). For the rural women, economic empowerment can be achieved through the concept of Self-Help Groups based on group approach to rural development. SHGs are definitely a boon to the rural poor women who undertake workable economic activities on their own. SHGs are voluntary association of people formed to accomplish some common goals. In this paper, an attempt has been made to evaluate the type of business and its performance carried out by women SHGs members and its impact on economic empowerment in rural areas.

Keywords: Empowerment, Development, Self-Help Groups.

\section{Introduction}

"Gaon Bade To Desh Bade" is the motto of National Bank for Agriculture and Rural Development(NABARD) which is very correct for a country like India whose 70 percent population resides in $6,38,345$ villages and 24 crore poor are occupied in microenterprise activities. Poverty in India is widespread with the nation estimated to have one third of world's poor. Women empowerment is the most important device for the socio-economic development of a nation.

\footnotetext{
* Research Scholar, Dept. of Commerce, University of Lucknow. ** Lecturer, Dept. of Commerce, NKMV Lucknow.
} 
Bringing women into the mainstream is one of the main challenges for every government. Self -Help Groups have emerged as the tool that wields power to create a socio- economic revolution in the our country. Self help groups have not only produced tangible assets and improved living condition of SHG members but also helped in changing their outlook, worldview and attitude. Women in India are the victims of several socio-economic and cultural factors. Emancipation of women is a precondition for economic development and social upliftment of a country.

The Self Help Groups (SHGs) have paved the way for socioeconomic independence of rural women. The members of SHGs are engaged in income generating activities and Micro -Entrepreneurships. Through these IAGs they are becoming economically independent and providing employment opportunities to others. Women consist of half of human resources they have been recognized as key agents of sustainable development and women's equality is as vital to a more holistic approach towards stabilizing new patterns and process of development that are sustainable. The contribution of women and their position in the family as well as in the economic development and social transformation are pivotal.

Women constitute 90 per cent of total marginal workers of the country. Rural women who are engaged in agriculture form 78 per cent of all women in regular work. Men and the project administrator's act as the critical components that determine their extent to which empowerment may or may not take place. The role of micro-credit is to, improve the socio and economic development of women and improve the status of women in households and communities. The micro entrepreneurships are strengthening the women empowerment and remove the gender inequalities. Self Help Group's micro credit mechanism makes the members to involve in other community development activities. Micro credit is promoting the small scale business enterprises and its major aim is to alleviate poverty by income generating activities among women and poor.

A series of development programmes have been implemented for the development of economy in general ignoring women who constitute 
50 percent of the total population. Role of women in development is an indispensable factor. Development programmes no longer can achieve their target without the participation and contribution of women. The role of women and need to empower them are central to human development programmes including poverty alleviation. In spite of safeguards provided in many of poverty alleviation programmes, it was observed that women in rural areas especially from poor families could not be benefited. All provisions of the Constitutions and the spate of legislation enacted to empower women in the post-independence India have not been adequate to set women free from their traditional bondages, liabilities and restrictions. Till recent times, women's participation in the decision making processes especially in rural areas have remained very marginal.

SHGs are believed to be the vehicle for women empowerment and poverty alleviation. According to the Planning Commission of India SHG is a self-governed, peer controlled small and informal association of the poor, from socio-economically homogeneous families who are organised around savings and credit activities. Members of SHGs meet weekly or monthly and discuss common problems and share information to come at a solution. Group members make effort to change their economic and social problem through mutual assistance. Though the concept of SHGs was piloted by NGOs namely MYRADA in India in Mid 80 's but the progress remained low until NABARD took over this project in 1992. What started as a pilot program has now become a movement for social Empowerment particularly for rural poor women. The no. of SHG's linked to banks has increased from about 500 in the early 1990 s to more than 1.6 million in 2006. The SHG strategy has become an important component of the Government's overall thurst to mitigate poverty and has been included in every annual plan. Lot of research work has been undertaken to measure the impact of SHG movement on socio-economic empowerment of women which has been summerised below. 


\section{Review of Literature}

Few studies are available on SHG and micro-finance and women empowerment. The researcher has tried to review the following:

Osman (2000) in his article remarked that micro-finance schemes alone can not alleviate poverty. The battle for total eradication of poverty requires combining micro-finance schemes with parallel, complementary programmes addressing the social and cultural dimensions of want, privation, impoverishment and dispossession.

Kapur (2001) in her study tried to discuss, analyse and answer the challenging questions as to why despite all the efforts and progress made, still there continues to be so much of gender discrimination and what strategies, actions and measures to be undertaken to achieve the expected goal of empowerment. She opined that women's empowerment is much more likely to be achieved if women have total control over their own organisations, which they can sustain both financially and managerially without direct dependence on others.

Pattanaik (2003) in her study reveals that SHGs are continuously striving for a better future for tribal women as participants, decisionmakers and beneficiaries in the domestic, economic, social and cultural spheres of life. But due to certain constraints like gender inequality, exploitation, women torture for which various Self Help Groups are not organised properly and effectively.

Malhotra (2004) in her book has examined how women entrepreneurs affect the global economy, why women start business, how women's business associations promote entrepreneurs, and to what extent women contribute to international trade. It explores potential of micro-finance programmes for empowering and employing women and also discusses the opportunities and challenges of using micro-finance to tackle the feminisation of poverty. According to her, the micro-finance programmes are aimed to increase women's income levels and control over income leading to greater levels of economic independence. They enable women's access to networks and markets, access to information and possibilities for development of other social and political role. They 
also enhance perceptions of women's contribution to household income and family welfare, increasing women's participation in household decisions about expenditure and other issues leading to greater expenditure on women's welfare.

Narasaiah (2004) in her study mentioned that the change in women's contribution to society is one of the striking phenomena of the late twentieth century. According to him micro-credit plays an important role in empowering women. Giving women the opportunity to realise their potential in all spheres of society is increasingly important.

Cheston \& Kuhn (2004) in their study concluded that micro-finance programmes have been very successful in reaching women. This gives micro-finance institutions an extraordinary opportunity to act intentionally to empower poor women and to minimise the potentially negative impacts some women experiences.

Manimekalai (2004) in his article commented that to run the income generating activities successfully the SHGs must get the help of NGOs. The bank officials should counsel and guide the women in selecting and implementing profitable income generating activities. He remarked that the formation of SHGs have boosted the self-image and confidence of rural women.

Sahu and Tripathy (2005) in their edited book views that 70 per cent of world's poor are women. Access to poor to banking services is important not only for poverty alleviation but also for optimising their contribution to the growth of regional as well as the national economy. Self Help Groups (SHGs) have emerged as the most vital instrument in the process of participatory development and women empowerment. The rural women are the marginalized groups in the society because of socio-economic constraints. They remain backward and lower position of the social hierarchical ladder. They can lift themselves from the morass of poverty and stagnation through micro finance and formation of Self-Help Groups.

Das Gupta (2005) in his article commented that a paradigm shift is required from "financial sector reform" to "micro-finance reform". While the priority sector needs to be made lean, mandatory micro credit must be monitored rigorously. Simultaneously space and scope 
have to be properly designed for providing competitive environment to micro-finance services. Extensive database needs to be created by the RBI for understanding micro-finance.

Sinha (2005) in his study has observed that micro-finance is making a significant contribution to both the savings and borrowing of the poor in the country. According to him the main use of micro-credit is for direct investment. There is of course some fungibility, depending on household credit requirements at the time of loan disbursement. Some studies reveal that micro-finance programmes have had positive as well as negative impacts on women.

United Nations (2006) a survey of bank managers in Madhya Pradesh revealed a perception that women borrowers were more trustworthy and less of a default risk. This can work as a benchmark for launching new schemes for women empowerment.

\section{Objectives}

The objectives of the present study are to study the Pre- and PostSHG status of SHG women members and to evaluate the impact of SHGs in empowering women.

\section{Research Methodology}

The present study is undertaken in Allahabad district of Uttar Pradesh. Both Primary and secondary data have been used for the present study. Random sampling method has been used for the selection of 150 women beneficiaries from the SHGs in Allahabad district. In order to study the impact of SHG on the women beneficiaries, the occupation of the respondents in pre and post SHG stage has been analyzed. Similarly the income of the respondents in pre and post SHGs stage has been taken for the study and other socioeconomic parameters have been examined to study the impact of SHGs in empowerment of beneficiaries.

\section{Analysis of data}

The major objective in initiating SHGs for women, especially the poor women is to help them take up and manage their productive activities. This could increase their household income leading to improved standard of living. Such income generating activities 
(IGAs) are also expected to serve as instruments which could bring about economic independence and empowerment among the women SHG members. The impact of SHGs are analyzed on the basis of occupation of the respondents in Pre-SHG and Post -SHG stage, income of the members in Pre-SHG and Post- SHG stage, benefits and empowerment through SHGs.

Table No. 1: Occupation of respondents in Pre SHG and Post

SHG stage

Occupation of the Respondents in pre and post SHG stage

The occupation of the respondents in Pre and Post stage has been analyzed in the above Table No. 1 . It is shown in the above table that 32 percent of the respondents have no occupation in Pre-SHG stage where as in Post- SHG stage only 8 percent of the respondents are without occupation. The occupation chosen by SHG members depends upon the availability of resources, demand for the product in the market and skill of the members. 
Table No. 2: Income of the respondents in Pre SHG and Post SHG stage

\section{Income of the Respondents in Pre and Post SHG stage}

The SHG members get occupied in activities which yield improved income to them. The income of the respondents in Pre-SHG and Post SHG stage is analyzed in the above Table. It is evident that before joining in Self-Help Groups, $32 \%$ of the respondents had no income and none of the respondents had income above Rs.5000. After joining SHG, three percent of the respondents have income above Rs.5000 per month. In post- SHG none of the single beneficiary coming under no income group. Before joining SHG majority of the women were unable to contribute towards their family income as they do not have the skills or opportunities for employment. After joining SHG though the returns from income generating activity (IGAs) taken up remain irregular and many cases unstable, they would make a lot of difference to the lives of poor. The increased income has helped to supplement the incomes to reduce the level of the poverty to a great extent in several families. 
Table No. 3: Empowerment of Self -Help Group Women

Empowerment of Self-Help Group Women

The SHG program mainly focuses on empowerment of rural women and making them financially socially and politically capable. The above table analyses the empowerment of SHG women in the study area. Table 3 reveals the opinion of the respondents regarding the women empowerment through SHGs. The respondents were able to contribute towards their family income and also counted other benefits like skill upgradation, better understanding, better leadership and communication skills etc. They gain firsthand experience of how to take decisions in community, village, and in households. Most important is that there is palpable improvement in standard ofliving.

\section{Summary of Findings}

On the basis of the study the following findings are as under

$>32$ percent of the respondents have no occupation in Pre-SHG stage where as in Post -SHG stage, only 8 percent of the respondents are without occupation. 
$>$ In Pre -SHGs stage, 26 percent of the respondents were engaged in tailoring, but in post -SHGs stage, the figure decline to 18 percent.

$>$ In Pre-SHGs stage, 8 percent of the respondents are engaged in other income generating activities which increased to 42 percent in post-SHGs stage.

$>$ Before joining in Self-Help Groups, 32 percent of the respondents had no income and none of the respondents had income above Rs.5000 per month. After joining SHG, 3 percent of the respondents have income above Rs.5000 per month. In post -SHG stage, not a single beneficiary is coming under no income group.

$>$ In pre-SHGs stage, majority of respondents i.e. 44 percent are having income ranging between Rs.1000-2500 per month but after joining SHGs, 54 percent of respondents mentioned that their income have increased to Rs.25005000 per month.

$>$ Majority (96 percent) of respondents have opined that through SHGs, they are able contribute towards their family income, 46 percent of respondents have expressed that SHGs have helped them for skills upgradation, 52 percent of respondents have opined that their standard of living have improved after joining SHGs, whereas 60 percent of the respondents have opined that SHGs have improved their better leadership and communication skill and 52 percent of respondents stated that after joining SHGs, they are able to take decision in community, village and household activities. SHGs have a power to create a socio economic revolution in the rural areas of our country.

\section{Suggestions}

$>$ The government should provide infrastructure for training of SHG members in micro-enterprise and also marketing infrastructure for marketing of the products.

$>$ Strong marketing network is required for effective and proper 
marketing of products and services of micro-enterprise linked SHGs. They need marketing support and institutional capacity to handle marketing activities independently. Multiple Enterprises development programmes are to be organized so that awareness for setting up of microenterprises could be attained.

$>$ The availability of natural resources, skills and potentiality is to be thoroughly analyzed while initiating the microenterprise. Concerned government official should counsel, advice and support the SHG members in this regard.

$>$ In-spite of the existence in group mode for more than a decade, the groups dynamics still not strong and awareness about group objectives beyond thrift and credit at member level was limited. Capacity building for the group members should be a continuous process.

$>$ Select a few Mandal Samakyas and support livelihood projects based on local resources and skills to promote entrepreneurship and give required confidence to groups to manage the business operations.

$>$ Entrepreneurial and management skills such as risk bearing, enterprise planning, product innovation, need perseverance, financial resource mobilization, production, marketing demand forecasting, cost control, HR related aspects should be properly imparted among the SHG members for commercial viability of the enterprise.

\section{Conclusion}

SHG is a powerful instrument for poverty eradication in the new economic era. As women are the most vulnerable section of the society the quick progress of SHG is an upward vehicle for women empowerment. SHGs have not only produced tangible assets and improved living condition of members but also helped in changing much of their outlook and attitude. In the present study, it has been found that SHGs have served the cause of women empowerment, social-solidarity and socio-economic betterment of poor rural 
women. SHG serves as a democratic tool for grassroot development for women. SHG promotes self reliance by generating its own funds. It breaks the vicious cycle of debts. It is an effective agent for change and serves as a solid platform for women empowerment.

\section{References}

Bosch, Ellie (2002), Micro-finance: New Wine in a New Bottle, A Supplementing Role for Cordaid and IICO, March.

Censuses of India, C series, RGI, New Delhi, 2001.

Cheston, Susy and Lisa Kuhn (2002), "Empowering Women Through Microfinance", Unpublished Background Paper for the Micro-credit Summit 15, New York, 10-13 November (www.microcreditsummit.org).

Dasgupta, Rajaram (2005). "Microfinance in India: Empirical Evidence, Alternative Models and Policy Imperatives", Economic and Political Weekly, 19 March.

\section{District Statistical Handbook, Gajapati (2000).}

Kabeer, N. (2001), "Resources Agency Achievements: Reflections on the Measurement of Women's Empowerment - Theory and Practice", SIDA Studies, No. 3.

Kapoor, Pramilla (2001), Empowering the Indian Women, Publications Division, Ministry of Information and Broadcasting, Government of India.

Malhotra, Meenakshi (2004), Empowerment of Women, Isha Books, Delhi.

Manimekalai, K. (2004), "Economic Empowerment of Women Through Self-Help Groups", Third Concept, February.

Narasiah, M.L. (2004), Women and Microcredit, Sonali Publications, New Delhi.

Osman, Khalil, "Microfinance Institutions: Effective Weapon in the War against Rural Poverty", www.muslimedia.com.

Pattanaik, Bijoy Kumar, "Smaranika, 2003”, Gajapati at a Glance.

Pattanaik, Sunanda, “Smaranika, 2003”, Empowerment through SHG: A Case Study of Gajapati District.

Sahu and Tripathy (2005), Self-Help Groups and Women Empowerment, Anmol Publications Pvt. Ltd., New Delhi.

Sinha, Frances (2005), "Access, Use and Contribution of Micro-Finance in India: Findings from a National Study", Economic and Political Weekly, April 23. 